\title{
Why The SEC Is Delaying Adoption Of International Financial Reporting Standards
}

Clemense Ehoff Jr., Ph.D., Berkeley College, USA

Dov Fischer, Ph.D., SUNY Empire State College, USA

\begin{abstract}
In 2002, the Financial Accounting Standards Board (FASB) and the International Accounting Standards Board (IASB) formally began a process to converge Generally Accepted Accounting Principles (GAAP) and International Financial Reporting Standards (IFRS). The SEC has repeatedly delayed its decision on whether to adopt International Financial Reporting Standards as the financial reporting system for U.S. public companies, continue with the convergence project, or reject IFRS altogether. This paper will examine several key reports issued by the SEC and the Financial Accounting Foundation to gain further insight into 1) why the SEC has repeatedly delayed its decision, and 2) what the SEC will ultimately decide.
\end{abstract}

Keywords: IFRS; GAAP; SEC; Financial Reporting Standards

\section{INTRODUCTION}

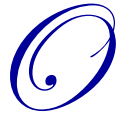

n September 18, 2002 the Financial Accounting Standards Board (FASB) and the International Accounting Standards Board (IASB) formed a memorandum of understanding, known as the Norwalk Agreement (FASB, 2002). The purpose of the Agreement was for both Boards to work jointly on the development of high-quality accounting standards, suitable for domestic and international financial reporting, and to revise existing differences in standards, with the aim of achieving greater (if not complete) compatibility between Generally Accepted Accounting Principles (GAAP) and International Financial Reporting Standards (IFRS). If a high degree of compatibility could be achieved, movement to IFRS by the United States would be relatively painless.

Many in the U.S. business community expected the Securities and Exchange Commission (SEC) to adopt, reject, or incorporate IFRS by June 2011, or at the latest, by the end of 2011. Unfortunately, the SEC has yet to make its decision. At a February 2012 conference, SEC Commissioner Mary Schapiro indicated that she would not be rushed into making this decision, nor would she be pressured into doing so (Huff Post Business, 2012). With no date for a decision in sight, and only four months remaining in 2012, it seems likely that Schapiro's IFRS decision will not come before sometime in 2013.

During the last two years, the SEC Staff has been extremely active in analyzing a possible move to IFRS. In this paper, we will examine several key reports issued by the SEC Staff, and one report issued by the Financial Accounting Foundation (FAF) to gain further insight into 1) why the SEC has repeatedly delayed its decision, and 2) what the SEC will ultimately decide.

\section{SEC STAFF CONDORSEMENT PAPER}

Despite more than nine years of joint effort by the FASB and the IASB on the Norwalk Agreement, more than 100 differences remained between GAAP and IFRS (Staff of the U.S. SEC, 2011 - A Comparison of U.S. GAAP and IFRS). It became clear that full adoption of IFRS (and complete abandonment of U. S. GAAP) as of a specific date was unlikely any time in the near future. Transitioning to IFRS over a period of years seemed more likely. To keep things moving, on May 26, 2011, the SEC issued a staff paper (SEC Staff, 2011. Exploring a Possible Method of Incorporation) outlining a possible method of incorporating IFRS into US GAAP through what 
is commonly known as Condorsement - a combination the Convergence and Endorsement approaches. As background, the staff paper defines the convergence and endorsement approaches and illustrates their use in actual practice.

Under the Convergence approach, a country (also referred to as a jurisdiction) does not adopt IFRS as its financial accounting standards. Instead, local standards are maintained and converged (or modified) over time to align closer (or completely) with IFRS. China's Accounting Standards for Business Enterprises (ASBE) is offered as an example of the Convergence Approach (SEC Staff, 2011, Exploring, p. 5). Standard-setting authority does not shift to the IASB, it remains with the specific country.

Under an Endorsement approach, a country incorporates IFRS into its local body of standards. Each IFRS standard is reviewed by the endorsing country and integrated into its existing standards by either complete or partial adoption, or rejected entirely. Countries belonging to the European Union (EU) follow the Endorsement Approach. The EU has adopted all of the international accounting standards with the exception of hedge accounting. That standard has been has been partially adopted, referred to as a carve-out. (SEC Staff, 2011, Exploring, pp. 5-6) Although standard-setting authority remains with the specific country, new standards are developed by the IASB.

Condorsement, as proposed by the SEC staff, is a combination of the Convergence and Endorsement approaches described above. Standard-setting authority would remain with the U.S., through the FASB, the SEC's delegate. Convergence work would continue, bringing existing GAAP closer to IFRS. Existing IFRS would be incorporated into U.S. GAAP over a defined time period, perhaps five to seven years. If all goes well, at the end of this period, a U.S. public company, compliant with GAAP, would also be compliant with IFRS (SEC Staff, 2011, Exploring, p. 7). For the endorsement component, the FASB would participate in the development of new standards, but its role in the process would change significantly from what it was in the past. The principal body responsible for standard development would be the IASB. The FASB's role would be that of promulgator of U.S GAAP through its endorsement of IFRS promulgated by the IFRS. The FASB would retain the right to modify or add requirements to the incorporated IFRS. However, the SEC proposal envisions those situations as extremely rare and typically avoidable (SEC Staff, 2011, Exploring, pp. 8-10). Standard setting authority would remain with the FASB and the SEC, its overseer, until full adoption has been achieved. (SEC Staff, 2011, Exploring, pp. 11-12) At the end of the report, the Staff asked for feedback on its report.

The endorsement component of the proposal seems to characterize the FASB as s facilitator, charged with a primary duty of "selling" new standards to the U.S. business community. The FASB could certainly discuss significant objections with the IASB, but the Staff Report envisions objections as extremely rare. The FASB's role is characterized as an educator and promoter of IFRS. The FASB would still be in the position to add guidance to standards as they are incorporated into GAAP.

After nine years of FASB/IASB work on joint projects and two announced deferrals, the Condorsement paper signaled the business community that the SEC might be ready to bring the issue of International financial standards to a conclusion. The proposed shift of standard-setting authority from the SEC (through the FASB) to the IASB was now "on the table," and could become a reality in a matter of months. It was clear that serious consideration would be given to this proposal.

\section{FAF RESPONSE TO CONDORSEMENT PAPER}

The FAF wasted little time in making its views known. On November 15, 2011, John Brennan, Chairman of the Financial Accounting Foundation (FAF), the overseer of the FASB, issued a comment letter to the SEC Staff sharing the FAF's views on the Condorsement paper (Brennan, 2011). The FAF supported the Condorsement approach, agreeing with the following fundamental concepts of Condorsement:

- $\quad$ The proposal shows U.S. commitment to developing global accounting standards.

- $\quad$ The proposal retains U.S. GAAP as the basis for U.S. financial reporting.

- The proposal retains U.S. sovereignty over Standards applicable in U.S. capital markets, and provides an endorsement structure for incorporating IFRS. 
- $\quad$ The proposal recognizes that jurisdictional and cultural differences may prevent complete agreement of high-quality accounting standards.

- $\quad$ The proposal allows for a gradual transition of U.S. GAAP to IFRS. (Brennan, 2011. p. 2).

The FAF listed the following areas that, in their opinion, require refinement:

- $\quad$ Standard setting authority for U.S. GAAP moves from the SEC to an international body.

- $\quad$ The authority transfer comes early on in the Condorsement approach.

- The reduced role and influence of the U.S standard setter could affect the quality of financial reporting standards (Brennan, 2011. p. 2).

The FAF made four important recommendations to the SEC Staff's proposal. First, the U.S. would retain sovereign authority over financial statement reporting and standard setting for U. S. markets. Second, the joint projects undertaken by the FASB and IASB would continue to their completion, but no new projects would be undertaken. Third, the FASB would refrain from separate standard setting for new projects. However, the FASB members would actively participate in IASB deliberations, schedule regular and frequent meetings between the FASB and IASB concerning new standards and issues of particular interest to the U.S. (Brennan, 2011. p. 3). Finally, the FASB would evaluate IFRS one standard at a time and incorporate it into U.S. GAAP only if it improved the financial reporting quality of existing U.S. GAAP, otherwise it would not be incorporated.

If the SEC Staff's Condorsement Approach can be characterized as a passive transition to IFRS, then the FAF version can certainly be viewed as an aggressive defense of U.S. GAAP. Clearly, the FAF is against discarding U.S. GAAP, and relinquishing U.S. standard-setting authority.

\section{SEC STAFF FINAL REPORT}

On July 13, 2012, the SEC staff issued a final report summarizing the activities and analyses of the SEC staff with respect to the potential impact of incorporating IFRS into the U.S. financial reporting system. (SEC Staff, 2012. Final Staff Report). This 127page report is an excellent foundation for those unfamiliar IFRS incorporation issues, and is useful in advanced accounting classes as the basis for a research project.

The Final Staff Report draws no conclusion, nor does it make any recommendation as to the best course of action for the SEC, with respect to incorporating IFRS into the U.S. financial reporting system. Instead, the report points to some significant matters worth considering before any decision is made. A few of those matters follow.

In its report, the Staff noted that the IASB has made considerable progress in developing a comprehensive set of accounting standards (SEC Staff, 2012, Final Staff Report, p. 4). However, the IFRS is not comprehensive with respect to certain industries and lacks broad guidance for utilities, insurance, extractive activities, and investment companies. (Final Staff Report, p. 8). The Staff noted that U.S. GAAP is a mature set of standards that has typically tailored itself to business needs, offering guidance as required. In contrast, the IASB uses generally applicable principles instead of specific industry guidance (Final Staff Report, p. 17). There remains more than 100 differences between IFRS and U.S. GAAP, such as impairment (Final Staff Report, p. 14), contingencies and environmental liabilities (Final Staff Report, p. 15), measurement of certain asset classes using a revaluation model (Final Staff Report, p. 15), inventory, research and development, income taxes (Final Report, p. 16), and property, plant, and equipment (Final Staff Report, p. 17). Although the Staff drew no conclusions from their analysis, it is easy to see why many have concluded that U.S. GAAP is a more robust set of standards than IFRS.

\section{REASONS FOR THE DELAY}

SEC Commissioner Mary Schapiro has not given any reason for delaying her IFRS decision, other than she has not completed her analysis and will not be pressured into doing so. The Condorsement paper, the FAF comment letter, and the SEC Staff Final Report reveal some of the reasons for the delay. 
The first reason for the delay is that since 2002, the FASB and the IASB have been working together to develop high-quality standards suitable for use in domestic and international financial reporting, bringing U.S. GAAP and IFRS closer together (convergence). The endeavor is still not complete. As mentioned in the SEC Staff Final Report, fundamental differences remain between U.S. GAAP and IFRS.

The second reason for the delay is the notion that U.S. GAAP is a more robust set of standards that IFRS. As noted in the SEC Staff Final Report, IFRS lacks guidance for a certain number of industries, and concluded that overall, U.S GAAP is more comprehensive than IFRS.

The third and final reason for the delay concerns the shifting of standard-setting authority from the SEC to the IASB. Under the Condorsement Approach, standard-setting authority shifts from the SEC to the IASB, first with the development of new standards, and then eventually with all standards under full adoption. The transfer of standard-setting authority is a serious matter, requiring much analysis and thought. In a prior paper (Ehoff \& Fischer, 2012), we reviewed the adoption status of the world's ten largest powers. Four countries have chosen the convergence path: the United States, China, Japan, and India. Six countries have chosen the endorsement approach: Germany, Russia, the United Kingdom, Brazil, France, and Italy. None of the world's ten largest economic powers have gone to full adoption. It seems that the world powers are reluctant to give up standard-setting authority. We have seen the EU incorporate most the IFRS standards, carving out the hedging standard to suit their own needs. Carve-outs hamper comparability, the main reason for establishing a common set of standards. Picking and choosing standards then becomes an activity similar to visiting a salad bar, where the diner customizes his salad to suit himself. Clearly, the SEC is not interested in that approach and would prefer to remain in the convergence mode and exercise complete authority over its financial standards.

\section{CONCLUSION}

Over the years, IFRS has made positive strides. Many countries are moving closer to a common set of financial reporting standards. However, in the fashion of an old slogan, close only counts in horseshoes, hand grenades, and now IFRS. We have raised the following question before. If the SEC's mission is to protect U.S. investors, how is abandoning oversight authority over financial reporting standards for public companies in the best interest of U.S. investors? In our opinion, when the SEC finds a satisfactory answer to that question, the U.S. will set a path to full adoption of IFRS. Otherwise, the SEC position will remain as it is.

\section{AUTHOR INFORMATION}

Dr. Clemense Ehoff Jr., CPA is an Accounting Professor at Berkeley College, Woodland Park, New Jersey. He holds a Ph. D in Business Administration from San Francisco's Golden Gate University. He has more than 30 years professional business experience and has held full-time faculty and adjunct positions at universities predominantly in the Eastern United States. Over the last ten years, Dr. Ehoff has been involved in teaching accounting and tax courses in an online platform. He operates a consulting and tax practice. He has published articles in Elevator World, and other journals. E-mail: drehoff@comcast.net (Corresponding author)

Dr. Dov Fischer is Assistant Professor of Accounting, SUNY Empire State College, Staten Island, New York. He holds a Ph.D. in Business Administration from the University of Colorado at Boulder. His dissertation on investor reaction to news on drug firms won an award from the American Accounting Association. Over the last ten years, Dr. Fischer has taught in universities in New York, New Jersey, Canada, and Israel.

\section{REFERENCES}

1. Brennen, J. (2011). Re: SEC Staff Paper, Exploring a Possible Method of Incorporation (File No. 4-600). Retrieved on March 15, 2012 from http://www.journalofaccountancy.com/Web/20114810.htm

2. Ehoff, C. E. \& Fischer, D. (2012). Should the SEC Adopt International Financial Reporting Standards? Review of Business Information Systems - First Quarter 2012. Vol. 16, Number 1. 1-6.

3. FASB. 2002 The Norwalk Agreement. Retrieved June 15, 2011 from http://www.fasb.org/news/memorandum.pdf 
4. Huff Post Business, (February 24, 2012). Mary Schapiro, SEC Chief, Resists Push to Move to Global Standard. Retrieved on June 15, 2012 from http://www.huffingtonpost.com/2012/02/24/mary-schapiroglobal-accounging-standard_n 1299716.html

5. Staff of the U.S. Securities and Exchange Commission. (November 16, 2011). Work Plan for the Consideration of Incorporating International Financial Reporting Standards into the Financial Reporting System for U.S. Issuers. A Comparison of U.S. GAAP and IFRS. Retrieved on July 20, 2012 from http://www.sec.gov/news/press/2012/2012-135.htm

6. Staff of the U.S. Securities and Exchange Commission. (May 26, 2011). Work Plan for the Consideration of Incorporating International Financial Reporting Standards into the Financial Reporting System for U.S. Issuers. Exploring a Possible Method of Incorporation. http://www.sec.gov/spotlight/globalaccountingstandards/ifrs-work-plan-paper-052611.pdf

7. Staff of the U.S. Securities and Exchange Commission. (July 13, 2012). Work Plan for the Consideration of Incorporating International Financial Reporting Standards into the Financial Reporting System for U.S.

Issuers. Final Staff Report. Retrieved on July 20, 2012 from http://www.sec.gov/news/press/2012/2012$\underline{135 . h t m}$ 


\section{NOTES}

